\title{
Aikuisopintoihin osallistumisen kasautuminen ja esteet
}

Katajisto, Jukka. 1984. Aikuisopintoihin osallistumisen kasautuminen ja esteet. Aikuiskasvatus 4, 3, 139-143. - Artikkeli liittyy Aikuiskasvatuksen edellisen numeron s. 60-67 olleeseen artikkeliin Osallistumismuutokset Suomen aikuiskasvatuksessa 1972-1980. Artikkelissa tarkastellaan aikuiskasvatuksen alueellista ja sosiaalista kasautumista. Erikseen tarkastellaan aikuisopintoihin osallistuneiden ja osallistumattomien opiskeluvaikeuksia ja -esteitä. Artikkelin lopussa ehdotetaan eräitä toimenpiteitä aikuiskasvatukseen osallistumattomien opiskeluesteiden poistamiseksi.

\section{Osallistumisen kasautuminen}

Osallistuminen aikuisopiskeluun on monipuolistunut. Kun vuonna 1972 aikuisopiskelija oli jossain elämänsä vaiheessa osallistunut keskimäärin kahteen eri koulutusmuotoon, vuonna 1980 eri koulutusmuotoja oli keskimäärin kolme. Pääkaupunkiseudulla, jossa aikuisopiskeluun osallistutaan määrällisesti ja suhteellisesti eniten, osallistutaan myös useampiin erilaisiin koulutusmuotoihin kuin muualla maassa (Lankinen 1980, 19).

Aikuisopiskelu on keskittynyt suuriin asutuskeskuksiin kuten muukin osallistuminen kulttuuripalveluihin (Kulttuuritilasto 1981, 116-525). Tällöin muualla maassa korostuu perinteisten vapaan sivistystyön toimintamuotojen merkitys. Alueelliset erot osallistumisessa aikuisopiskeluun ovat kuitenkin olleet tasoittumassa vuodesta 1970 (taulukko 1; Katajisto 1983,25$)$.

Taulukko 1. Aikuisväestön osallistuminen aikuisopiskeluun suuralueen ja kuntamuodon mukaan vuosina 1972 ja 1980 (suluissa väestöryhmien jakaumat otoksissa) \%

\begin{tabular}{|c|c|c|c|}
\hline & $\begin{array}{c}\text { O s a llis t u m } \\
1.9 .1971-31.8 .1972 \\
\%\end{array}$ & $\begin{array}{c}\text { a j a n k o h t a } \\
1.9 .1979-31.8 .1980 \\
\%\end{array}$ & $\begin{array}{l}\text { Erotus } \\
1972-80 \\
\%\end{array}$ \\
\hline $\begin{array}{l}\text { SUURALUE }{ }^{1)} \\
\text { Helsinki } \\
\text { Muu Etelä-Suomi } \\
\text { Väli-Suomi } \\
\text { Pohjois-Suomi }\end{array}$ & $\begin{array}{l}30(10) \\
19(46) \\
20(33) \\
18(11)\end{array}$ & $\begin{array}{ll}29 & (10) \\
26 & (49) \\
25 & (28) \\
27 & (12)\end{array}$ & $\begin{array}{l}-1 \\
+7 \\
+5 \\
+9\end{array}$ \\
\hline $\begin{array}{l}\text { KUNTAMUOTO } \\
\text { Kaupungit } \\
\text { Muut kunnat }\end{array}$ & $\begin{array}{l}25(52) \\
15(48)\end{array}$ & $\begin{array}{l}28(62) \\
24(38)\end{array}$ & $\begin{array}{l}+3 \\
+9\end{array}$ \\
\hline YHTEENSÄ (\%) & $\begin{array}{l}20(100) \\
N=1440\end{array}$ & $\begin{array}{l}26(100) \\
N=3614\end{array}$ & +6 \\
\hline
\end{tabular}

1) Asuinalue suuraluejaon $\mathrm{m} \mathrm{u} \mathrm{k} \mathrm{a} \mathrm{a} \mathrm{n:}$

Muu Etelä-Suomi: muu Uudenmaan lääni paitsi Helsinki, Turun ja Porin, Hämeen ja Kymen läänit sekä Ahvenanmaa.

Väli-Suomi: Mikkelin, Pohjois-Karjalan, Kuopion, Keski-Suomen ja Vaasan läänit. Pohjois-Suomi: Oulun ja Lapin läänit.
Ammatillisessa aikuiskoulutuksessa on yhä selviä alueellisia eroja. Ammatilliseen aikuiskoulutukseen osallistuneiden osuus oli 197980 pääkaupunkiseudulla $26 \%$ ja muualla maassa 19-20 \% aikuisväestöstä. Yhteiskunnallisiin ja harrasteopintoihin osallistuneiden osuus oli taas eri puolilla maata melkein sama, eli $17-19 \%$. 
1970-luvun puolivälin jälkeen väestön keskittyminen asutuskeskuksiin on hidastunut. Taloudellisen kasvun hidastuminen on estänyt työvoiman liikkuvuutta. Maatalousväestö ei pienene enää yhtä nopeasti kuin ennen. Lisäksi toisen maailmansodan jälkeen syntyneet suuret ikäluokat ovat ohittaneet jo iän, jossa muuttoalttius on suurimmillaan. Väestönkehitys on tasapainottunut ja elinolosuhteet vakiintuneet.

Nämä tekijät ja ennen muuta lähes koko maan kattavat aikuiskoulutusorganisaatiot ovat tasoittaneet alueellisia eroja. Koulutuspolitiikkaa sekä sosiaaliturvaa ja muuta koulutusta koskevat aluepoliittiset toimenpiteet ovat myös vaikuttaneet tähän erojen tasoittumiseen (vrt. Valkonen et. al. 1980, 208-221).

Vaikka alueellinen kasautuminen onkin 1970-luvulla lieventynyt, näyttävät osallistumisen sosiaaliset erot yhä syvenevän osittain ammatillisen aikuiskoulutuksen voimakkaan laajenemisen seurauksena. Yhdellä toiminnan alueella aktiiviset henkilöt ovat aktiivisia myös muilla alueilla. Työnantajan järjestämään koulutukseen osallistuneet ovat aktiivisia myös vapaa-ajan opinnoissa, järjestötoiminnassa ja päinvastoin. Yksilöiden aktiivisuus ulottuu toisistaan varsin kaukanakin oleviin harrastusja osallistumismuotoihin. Toisaalta samat henkilöt jäävät jatkuvasti eri osallistumismuotojen ulkopuolelle.

Sosiaalisen osallistumisen kasautumista yksilötasolla on selitetty mm. ärsyke- ja menestyshypoteeseillä. Mitä enemmän ärsyketilanne muistuttaa aiemmin palkittua tilannetta, sitä todennäköisemmin toimitaan aiempaan tapaan (esim. Homans 1961; Allardt et al. 1956, Aaltonen-Manninen 1979, 221-229).

Eri väestöryhmien välillä on kuitenkin säännönmukaisia eroja. Miehet osallistuvat useampiin aikuisopintomuotoihin kuin naiset. Miehet osallistuvat ammatilliseen aikuiskoulutukseen toistuvammin ja koulutuspäivinä mitattuna kauemmin kuin naiset. Pidemmän koulutuksen saaneet 25-44 -vuotiaat toimihenkilöt ja yrittäjät (paitsi maatalousyrittäjät) käyttävät muita sosiaaliryhmiä useammin eri aikuiskoulutuspalveluita (taulukko 2).

Taulukko 2. Eri sosioekonomisessa asemassa olevien osallistuminen aikuisopintoihin joskus elämänsä aikana jaoteltuna osallistumismäärän mukaan vuonna $1980(\%)$

\begin{tabular}{|c|c|c|c|c|c|c|}
\hline \multicolumn{5}{|c|}{ OSALLISTUMISSKERTOJEN LUKUMÄÄRÄ ${ }^{1)}$} & $\begin{array}{l}\text { Haastateltuja } \\
\% 0\end{array}$ & $\begin{array}{l}\text { yht. } \\
\mathrm{N}\end{array}$ \\
\hline \multicolumn{7}{|l|}{ SOSIOEKONOMINEN } \\
\hline Maatalousyrittäjä & 38 & 45 & 15 & 1 & 100 & 137 \\
\hline Muu yrittäjä & 21 & 39 & 24 & 17 & 100 & 90 \\
\hline Ylempi toimihenkilö & 3 & 23 & 35 & 38 & 100 & 240 \\
\hline Alempi toimihenkilö & 7 & 44 & 32 & 17 & 100 & 734 \\
\hline Koulutettu työntekijä2) & 22 & 53 & 18 & 6 & 100 & 392 \\
\hline Kouluttamaton työntekijä & 34 & 48 & 15 & 3 & 100 & 636 \\
\hline Opiskelija & 45 & 42 & 11 & 2 & 100 & 391 \\
\hline Eläkeläinen & 47 & 36 & 12 & 5 & 100 & 614 \\
\hline Omaa kotitaloutta hoitava & 23 & 50 & 19 & 8 & 100 & 175 \\
\hline $\begin{array}{l}\text { Muu esim. avustava } \\
\text { perheenjäsen }\end{array}$ & 39 & 45 & 14 & 2 & 100 & 205 \\
\hline HAASTATELLUT YHTEENSÄ $(\%)$ & 28 & 43 & 19 & 10 & 100 & 3614 \\
\hline
\end{tabular}

Ammatilliseen aikuiskoulutukseen osallistuminen on myös jossain määrin keskittynyt toimi- ja ammattialoittain.

Koulutustarve on ilmaistu kaikilla toimialoilla suuremmaksi kuin toteutunut osallistuminen ammatilliseen aikuiskoulutukseen.

1) Haastattelulomakkeessa ja -ohjeissa yksilöitiin ja määriteltiin yhteensä 20 erilaista aikuiskoulutusmuotoa.

2) Vähintään neljän kuukauden ammatillisen koulutuksen saanut työntekijä.
Aloilla, joilla on ennestään hyvin koulutettua työvoimaa ja joilla aikuisopiskelumahdollisuudet ovat muita aloja suuremmat, työntekijät kokevat myös itse tarvitsevansa keskimäärin enemmän lisäkoulutusta (kuvio 1).

Kun teollisuudessa osallistuminen ammatilliseen aikuiskoulutukseen oli vuonna 1972 selvästi keskitason yläpuolella, se oli vuonna 1980 keskiarvon alapuolella (Lehtonen-Tuomisto 1973, 46). Tämä saattaa olla oire teknologian kehitysvaikutuksista. 
Kuvio 1. Työllisten osallistuminen ammatilliseen aikuiskoulutukseen 1.9.79-31.12.80 välisenä aikana sekä heidän ilmaisemansa tarve saada ammatillista lisäkoulutusta työtehtäviensä hoitamiseen toimialoittain $(\%)^{1)}$

TOIMIALA

Maa-, metsä- ja kalatalous

Kaivos- ja muu kaivannaistoiminta

Teollisuus

Sähkö-, kaasu- ja vesihuolto

Rakennustoiminta

Tukku- ja vähittäiskauppa, ravitsemus ja majoitustoiminta

Kuljetus ja varastointi

Tietoliikenne

Rahoitus-, vakuutus-, kiinteistö tms. toiminta

Opetus

Terveydenhoito

Kotitalouksia palveleva toiminta

Yhteiskunnalliset palvelukset

Yhteensä
Osallistunut ammattill.ak:een

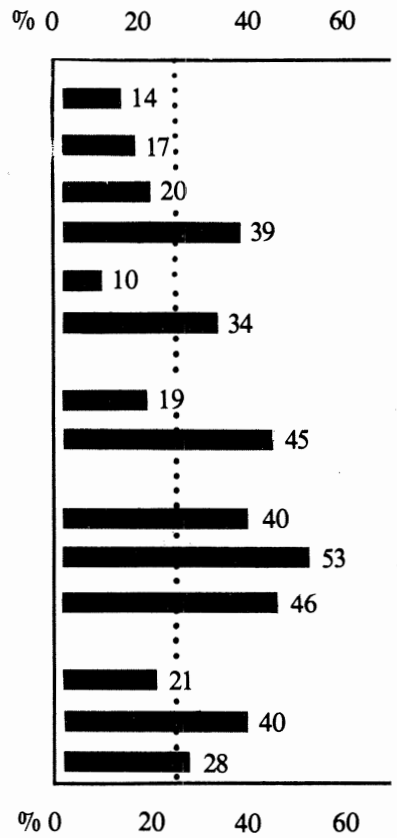

Tarvitsee ammatill. lisäkoulutusta

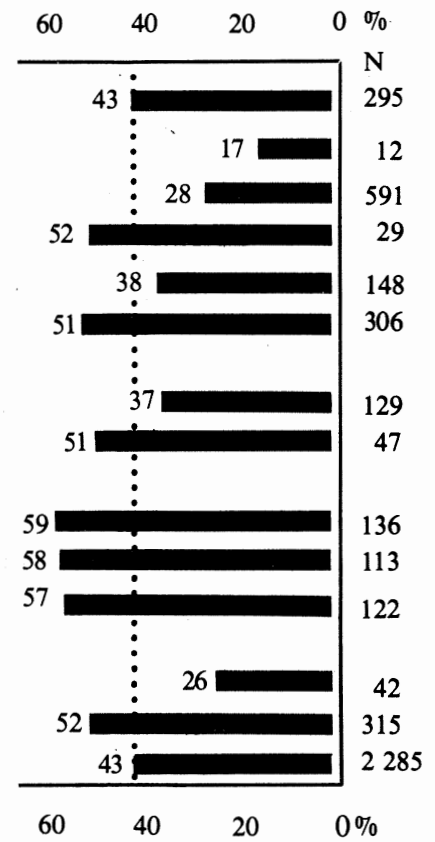

Taulukko 3. Tekijäryhmät, jotka estävät osallistumisen aikuisopiskeluun 1970-luvun tutkimusten mukaan

\begin{tabular}{|c|c|c|}
\hline $\begin{array}{l}\text { Koko maa } \\
(1972 \mathrm{~N}=1440)\end{array}$ & $\begin{array}{l}\text { Maaseutu } \\
(1977 \mathrm{~N}=594)\end{array}$ & $\begin{array}{l}\text { Pääkaupunki } \\
(1978 \mathrm{~N}=1578)\end{array}$ \\
\hline $\begin{array}{l}\text { 1) opetukseen liittyvät } \\
\text { asenne-esteet; } \\
\text { 2) aikaan liittyvät osallistu- } \\
\text { misesteet; }\end{array}$ & $\begin{array}{l}\text { 1) opetukseen liittyvät } \\
\text { asenne-esteet; } \\
\text { 2) palvelusten etäisyyteen ja } \\
\text { olemassaoloon liittyvät } \\
\text { tavoitettavuusesteet; }\end{array}$ & $\begin{array}{l}\text { 1) pelko opiskelu- } \\
\text { vaikeuksista; } \\
\text { 2) aikaesteet; }\end{array}$ \\
\hline $\begin{array}{l}\text { 3) opintomahdollisuuksien } \\
\text { tavoitettavuuteen liittyvät } \\
\text { esteet }\end{array}$ & $\begin{array}{l}\text { 3) vapaa-ajan käyttöön liittyvät } \\
\text { aikaesteet; }\end{array}$ & $\begin{array}{l}\text { 3) kriittinen asenne koulu- } \\
\text { tuksen merkitykseen; }\end{array}$ \\
\hline $\begin{array}{l}\text { 4) opiskelun merkityksettö- } \\
\text { myys. }\end{array}$ & $\begin{array}{l}\text { 4) ikääntymiseen ja vanhentu- } \\
\text { miseen liittyvät esteet; } \\
\text { 5) opiskelun tarpeettomaksi } \\
\text { tai kiinnostamattomaksi } \\
\text { kokeminen. }\end{array}$ & $\begin{array}{l}\text { 4) välinpitämättömät } \\
\text { opiskeluasenteet; } \\
\text { 5) rajoittavat elinolo- } \\
\text { suhteet }\end{array}$ \\
\hline $\begin{array}{l}\text { (Lehtonen-Tuomisto } \\
1973,186-212 \text { ) }\end{array}$ & $\begin{array}{l}\text { (Aaltonen-Manninen } \\
1979,105 \text { ) }\end{array}$ & $\begin{array}{l}\text { (Lankinen 1979, } \\
\text { 90-92) }\end{array}$ \\
\hline
\end{tabular}

1) Ammatilliseen aikuiskoulutukseen osallistuneista on rajattu lomaketeknisistä syistä pois ammatilliseen uudelleenkoulutukseen osallistuneet $(\mathrm{N}=58)$. Tämä tuskin olennaisesti muuttaa toimialojen mukaista osallistumisjakaumaa (Ammatilliseen perus-, jatko- ja täydennyskoulutukseen osallistuneiden $\mathrm{N}=638$ ). 
Aikuisopintoihin osallistumisella on taipumusta kasautua hyvin koulutetulle väestölle, jonka omassa hallinnassa on usein sekä työnsä että vapaa-aikansa käytön säätely. Siksi aikuisopetuksen kehittämisen haasteena ovatkin ne lyhyen koulutuksen saaneet ja alhaisessa sosiaalisessa asemassa olevat, joiden todennäköisyys joutua työttömiksi on suuri ja joilla ei ole koulutustarvetta työssä käydessään (Vrt. Hirsch 1980; Komiteanmietintö 1980: 55, $11-13,121-125)$.

\section{Osallistumisen esteet}

Aikuisopintoihin osallistumisen esteet on tiivistetty taulukkoon 3. eri tekijäryhmiksi faktorianalyysin avulla. Tekijäryhmät koskevat koko maata, maaseutua ja pääkaupunkia 1970luvulla.

Vuonna 1980 tiedusteltiin koko maassa aikuiskoulutushaastattelun osioluettelon avulla syitä aikuisopintojen vaikeutumiseen tai estymisęen. Kysymykset tehtiin sekä niille, jotka eivät olleet osallistuneet aikuisopintoihin että siihen osallistuneille. Vastaukset keskittyivät seuraavaan kahdeksaan osasyyhyn (Kuvio 2).

Kuvio 2. Aikuisopintoihin osallistuneiden ja osallistumattomien yleisimmät osallistumisvaikeudet. ja -esteet 1.9.79-31.12.80 välisenä aikana (\%)

OSALLISTUMISVAIKEUS

OSALLISTUMATTOMIEN OSALLISTUNEILLA OSALLISTUMISESTE

Ajan puute

Sopivia koulutusmahdollisuuksia ei ole riittävän lähellä

Väsymys työn jälkeen

Kiireet työpaikalla

Muut harrastukset vievät ajan

Hankalat työajat

Lastenhoito-ongelmat ja kotityöt

Vähäinen pohjakoulutus

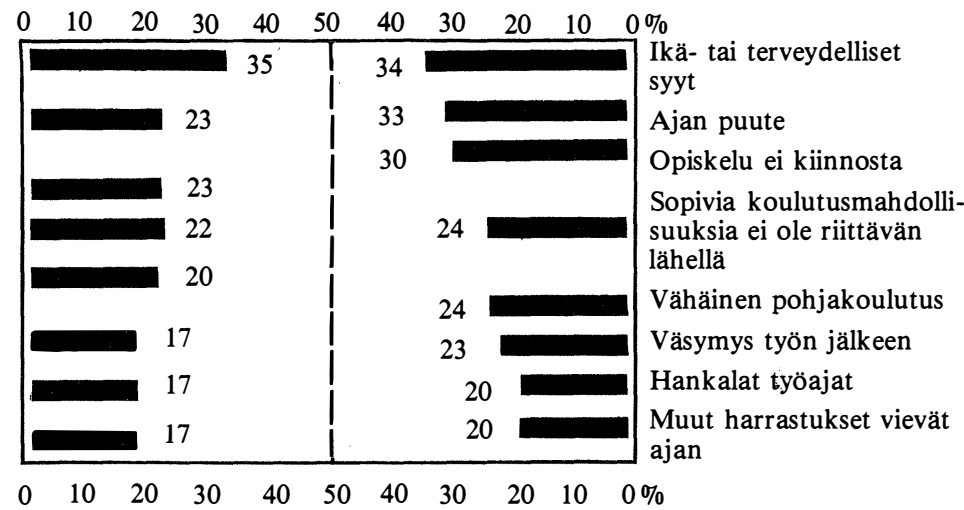

KYLLÄ -vastausten osuus kussakin osakysymyksessä

$$
\mathrm{N}=1309 \quad \mathrm{~N}=2305
$$

Työ, perhe-elämä, harrastukset ja muu vapaa-ajan käyttö toimintoina ovat nykyään yhä enemmän eriytyneet toisistaan. Siten näiden toiminta-alueiden joutuessa yksilön valinnoissa kilpailutilanteeseen on mahdollista, että aikuisopiskelussa, joka on vain yksi osallistumismahdollisuus monien muiden joukossa, ajan puute koetaan entistä korostuneempana lähes kaikkien yhteiskuntaryhmien arvostuksissa.

Helsingissä aikaesteet näyttävät suhteellisesti merkittävimmiltä kuin muualla. Maaseudulla taas ikääntymiseen ja koulutuksen tavoitettavuuteen liittyvät esteet ovat tärkeämpiä. (Aaltonen 1979, 17: Lankinen 1980, 30). Tämä on luonnollista, ovathan aikuisopiskelumahdollisuudet suurissa asutuskeskuksissa runsaat ja maaseudulla ikärakenne keskimääräistä korkeampaa. Sen sijaan välinpitämätön suh- tautuminen aikuiskasvatukseen - opiskelu ei kiinnostanut - korostui muuta maata enemmän ns. "Väli-Suomessa"' (ks. määrittely taulukon 1 alaviitteessä).

$\mathrm{Ne}$, jotka eivät osallistuneet aikuiskoulutukseen, kokivat estetekijät selvästi suuremmiksi kuin osallistuneet. Aikuiskoulutukseen osallistuneet pitivät työkiireitä, ajan puutetta ja lapsenhoitoon tai kotitöihin liittyviä esteitä kuitenkin suurempina. Osallistumattomien mielestä suurimpia esteitä olivat ikä, terveydelliset syyt ja se, ettei opiskelu kiinnosta.

Miehille ominaisia vaikeuksia tai esteitä osallistumiselle olivat muut harrastukset ja asennesyyt. Naisten opiskelua hankaloittivat olosuhteista johtuvat konkreettiset rajoitukset. Opiskeluesteiksi ei enää vuonna 1980 juurikaan koettu taloudellisia syitä, joskin niillä 
oli vielä selvästi merkitystä suoritustason työntekijöille ja omaa kotitaloutta hoitaville.

Monet osallistumisesteet ovat sellaisia ettei niihin voida paljonkaan vaikuttaa. Varsinkin aikuisten asenteiden muutos vaatii pitkäjänteistä didaktista kehittämistä koko koulutusjärjestelmässä. Sen sijaan useisiin olosuhteista johtuviin esteisiin voidaan vaikuttaa välittömästi. Sopivaa koulutustarjontaa voidaan lisätä sinne, missä siitä on puute. Aikaesteisiin voidaan vaikuttaa lisäämällä joustavia opintoja tutkintomahdollisuuksia eri koulutusjärjestelmien välillä. Opintotuki voidaan kohdistaa myös lyhytkestoiseen koulutukseen.

\section{Lopuksi}

Aikuiskoulutukseen osallistuminen on polarisoitumassa toisaalta vaativissa ammattitehtävissä toimivien sekä toisaalta vähän koulutusta saaneiden, apu- tai valvontatehtäviä suorittavien ja työttömien välillä. Koulutuksellisen tasa-arvon lisääminen edellyttää erityistoimenpiteiden suuntaamista niille, jotka eivät osallistu aikuisopintoihin. Aikaesteitä voidaan vähentää mm. joustavilla tutkinto- ja opintovapaajärjestelyillä. Olisi pyrittävä lisäämään erityisesti opintotukea lyhytkestoiseen koulutukseen myös muille kuin toimihenkilöille.

Tärkeintä on kuitenkin vaikuttaa asenteisiin koko kasvatus- ja koulutusjärjestelmässä elinikäisen kasvatuksen/jatkuvan koulutuksen periaatteen mukaisesti. Jos ihminen on jo peruskoulutusvaiheessa kadottanut uskon omiin oppimis- ja muihin mahdollisuuksiinsa, on aikuiskasvatuksen vaikea enää sitä palauttaa.

\section{Lähteet}

Aaltonen, R. 1979. Hindrances to Participation as an Object of Adult Education Research in Finland. Adult Education in Finland 4/1979. Helsinki.

Aaltonen, R. \& Manninen, H. 1979. Aikuisopiskelu ja kulttuuripalvelusten käyttö sosiaalisen osallistumisen muotoina. Aikuis- ja nuorisokasvatuksen laitoksen julkaisuja 13. Tampereen yliopisto.

Allardt, E., Jartti, P., Jyrkilä, F. ja Littunen, Y. 1956. Työläisnuorison harrastustoiminta. Helsinki.

Hirsch, J. 1980. Der Sicherheitsstaat. Das 'Modell Deutschland' seine Krise und die neuen sozialen Bewegungen, Frankfurt am Main 1980.

Homans, G. C. 1961. Social Behaviour. Its Elementary Forms. London.

Katajisto, J. 1983. Changes in Participation in Adult Education in Finland in the 1970's. Adult Education in Finland 2/1983. Helsinki.

Komiteanmietintö 1980:55. Teknologiakomitean mietintö. Helsinki.

Kulttuuritilasto 1981. Tilastotietoja taiteesta, tiedonvälityksestä, vapaa-ajasta, urheilusta ja nuorisotoiminnasta. Tilastokeskus, tilastollisia tiedonantoja n:o 73. Helsinki.

Lankinen, M. 1979. Aikuiskoulutuksen tila ja tarve Helsingissä. Helsingin kaupungin tilastokeskus. Tutkimuksia ja selvityksiä 1979:8, Helsinki.

Lankinen, M. 1980. Adult Education in Helsinki: Use and Need. Adult Education in Finland 2/1982. Helsinki.

Lehtonen, H. \& Tuomisto, J. 1973. Aikuiskoulutus Suomessa: Käsitykset ja käyttö. Yhteiskuntatieteiden tutkimuslaitos. Tutkimuksia A: 45. Tampereen yliopisto.

Valkonen, T., Alapuro, R., Jallinoja, R. ja Sanlund, T. 1980. Suomalaiset. Yhteiskunnan rakenne teollistumisen aikana. Juva. 


\section{Korjaus Aikuiskasvatus 3/84:ssä olleeseen artikkeliin}

Jukka Katajiston Aikuiskasvatus-lehden 3/84 artikkelissa "'Aikuisopintoihin osallistumisen kasautuminen ja esteet" taulukon 2 otsikossa aikuisopintoihin osallistumisen jaottelu oli mainittu virheellisesti "osallistumismä̈̈rän" mukaan (s. 140), kun se olisi pitänyt olla "aikuiskoulutusmuotojen" määrän mukaan. Samoin taulukkopää olisi pitänyt luokitella osallistumismuotojen lukumäärän mukaan 0 , $1-2,3-4$ ja yli 4 osallistumismuotoa, eikä osallistumiskertojen lukumäärän mukaan. 